\title{
Rapa Nui Language
}

National Cancer Institute

\section{Source}

National Cancer Institute. Rapa Nui Language. NCI Thesaurus. Code C154085.

An Eastern Polynesian language spoken on the island of Rapa Nui (Easter Island). 